\title{
Testing of Banking Services in Bangladesh: A Study on Prime Bank Limited Rangpur Branch
}

\author{
Md. Zahid Hossain ${ }^{1}$, Md. Tareque Quddus² \\ ${ }^{1}$ Assistant Professor, Department of Marketing, Begum Rokeya University, BANGLADESH \\ ${ }^{2}$ Assistant Professor, School of Business, Asian University of Bangladesh, BANGLADESH
}

\begin{abstract}
Customer satisfaction is asset. At present clients are so much conscious and sensitive about the services what they receive. The study focused on testing of banking services in Bangladesh to know the gap between customer expectation and customer satisfaction. Findings of the study clearly suggest that clients are overall satisfied, and their attitude is very positive towards Prime Bank Limited Rangpur Branch. It also shows that they are not delighted with existing services. The study recommends putting more attention for the services, providing something new to the customers to gain competitive advantage and have an impact for a long time and help developing the sector with a fair competitive environment.
\end{abstract}

Keywords: services, bank, service quality, customer satisfaction, empirical

\section{INTRODUCTION}

The present world is changing rapidly to face the challenge of the competitive free market economy. At the present competitive age, proper marketing of services is a necessity for customer satisfaction, and customer satisfaction is a necessity to survive in the market at the long run. So the importance of service marketing is much greater. The banking sector faces a stiff competition in providing services. So they always try to provide better client service. As they try to provide better client service, testing of their services time to time is much needed. This analytical study tried to focus on that for all the banking organizations.

Before selecting a bank, each customer expects certain types of service from the bank. If there is a gap or discrepancies between the customer perception and management perception of a bank, then it influences the customer. These gaps may be created from the following issues such as word-of-mouth communication, personal needs, expected service, past experience, bank service, actual service delivery, management perception of customer, external communication, service value, image value, monetary cost, time cost, energy cost etc. Prime bank Limited started its operation as a commercial bank on April 17, 1995. At present it has 136 branches spread all over the country. Prime bank Limited, Rangpur Branch started its journey on December 02, 2007. Right now it is the only branch in Rangpur, Bangladesh. It provides products such as deposit accounts and schemes, loans, utility services and others. The bank is committed to provide high quality services to contribute to the growth of GDP, industrialization, boosting up export, creating employment opportunity for the educated youth, rising standard of living of limited income group and overall sustainable socio-economic development of the country.

\section{LITERATURE REVIEW}

High customer satisfaction leads to repeat visitation of stores, repeat purchase of products and services and wordof-mouth promotions to friends while low customer satisfaction associated with complaining behavior (Zeithaml, Berry and Parasuraman, 1996).

Zhang and Feng (2009) titled, 'The Impact of Customer Relationship Marketing Tactics on Customer Loyaltywithin Swedish Mobile Telecommunication Industry'. Findings showed that service quality, price perception, and value offers have an impact over customer loyalty.

If expectations are greater than the performance then the perceived quality is less than the satisfaction and hence customer dissatisfaction occurs (Parasuraman, Zeithamal, Berry, 1986). Lewis and Booms (1980) pioneered service quality research by defining service quality as a "Measure of how well the service level delivered matches the customer's expectations".

Customer satisfaction should be mentioned and managed just as any physical asset. Therefore, the business that hopes to prosper will realize the importance of this concept, putting together a functional and appropriate operational definition (McColl Kenedy \& Scheneider, 2000).

\section{ObJectives OF THE Study}

- To know the importance of services and customer satisfaction.

- To track clients' attitude towards the existing services.

- To find out service efficiency.

- To know about constraints and problems in providing services.

- To suggest a supportive role in the progress of banking sector. 


\section{MeTHODOLOGY}

This research is empirical in nature. Sample size was 56. Of them, 50 were clients (service holder 25, businessman 15 , housewife 05 , and student 05 ) and 06 were employees of the bank. Primary data collected from Prime Bank Limited, Rangpur Branch. Secondary data acquired from bank reports, websites, annual report, journals, articles, books, newspapers, etc. Data collected through depth interview for bank employees and personal interview for clients using survey questionnaire. Credit Section, billing Section, foreign exchange and deposit Sections were used to collect primary data. A pre-tested questionnaire has been used consist of open-ended, close-ended and dichotomous questions. Likert scale used for close-ended questions in the questionnaire.

\section{FINDINGS AND ANALYSIS}

Main reason for choosing Prime Bank Limited, Rangpur Branch

\begin{tabular}{|c|c|c|c|c|}
\hline $\begin{array}{c}\text { Personal } \\
\text { relation } \\
\text { with } \\
\text { banker }\end{array}$ & $\begin{array}{c}\text { Good or } \\
\text { efficient } \\
\text { service }\end{array}$ & $\begin{array}{c}\text { Effective } \\
\text { service } \\
\text { charges }\end{array}$ & $\begin{array}{c}\text { Employees } \\
\text { behavior }\end{array}$ & $\begin{array}{c}\text { Location } \\
\text { of the } \\
\text { bank }\end{array}$ \\
\hline 6 & 51 & & 3 & \\
\hline \multicolumn{5}{c}{ Source: Client' Survey Data } \\
\hline
\end{tabular}

The above data show that $85 \%$ of the clients prefer or choose this bank for good or efficient service, about $10 \%$ clients choose for personal relation with banker \& rest of the $5 \%$ clients chooses for employees' behavior.

Client's have knowledge about various types of banking products

\begin{tabular}{|c|c|}
\hline Yes & No \\
\hline 50 & 12 \\
\hline
\end{tabular}

Source: Client' Survey Data

From the above table it can be told that, $80 \%$ of the clients are well known about various types of existing policy (various types of deposit scheme, loan) \& others 20\% clients are not well known about this policy.

Convenience in getting electronic services than manual service

\begin{tabular}{|c|c|}
\hline Yes & No \\
\hline 48 & 12 \\
\hline
\end{tabular}

Source: Client' Survey Data

From the above table it can tell that, $80 \%$ of the clients are happy to it \& other $20 \%$ clients are not.

Clients want to spend time for taking service

\begin{tabular}{|c|c|c|}
\hline 5 to 10 minutes & 10 to 20 minutes & 20 to 30 minutes \\
\hline 30 & 18 & 12 \\
\hline \multicolumn{3}{|c|}{ Source: Client' Survey Data }
\end{tabular}

To see the above data it can tell that, $50 \%$ of the clients want to take service within 5 to 10 minutes \& $30 \%$ clients have willingness to take that service within 10 to 20 minutes \& rest of the $20 \%$ clients have willingness to take service within 20 to 30 minutes.

\section{Clients spend actual time to take service}

\begin{tabular}{|c|c|c|c|}
\hline $\begin{array}{c}5 \text { to } 10 \\
\text { minutes }\end{array}$ & $\begin{array}{c}10 \text { to } 20 \\
\text { minutes }\end{array}$ & $\begin{array}{c}20 \text { to } 30 \\
\text { minutes }\end{array}$ & $\begin{array}{c}\text { More than } \\
30 \text { minutes }\end{array}$ \\
\hline 10 & 20 & 20 & 10 \\
\hline \multicolumn{4}{|c|}{ Source: Client' Survey Data } \\
\hline
\end{tabular}

The above table show, 33\% clients, have told they have to spend within 10 to 20 minutes to take service \& another $33 \%$ clients have told they get service within 20 to 30 minutes \& $17 \%$ have told that they get service within 5 to 10 minutes \& another $17 \%$ have stated that they spend more than 30 minutes to get service.

\section{Reasonability of charges and interest rate

\begin{tabular}{|c|c|c|c|c|}
\hline $\begin{array}{c}\text { Strongly } \\
\text { agree }\end{array}$ & Agree & Neutral & Disagree & $\begin{array}{c}\text { Strongly } \\
\text { disagree }\end{array}$ \\
\hline & 6 & 6 & 30 & 18 \\
\hline \multicolumn{5}{r}{ Source: Client' Survey Data } \\
\hline
\end{tabular}

From the above table, it can tell that, the majority of the clients are highly dissatisfied for higher charges and interest rate.

Clients' satisfaction for existing bank products (loan, deposit scheme, money transfer \& others)

\begin{tabular}{|c|c|c|c|c|}
\hline $\begin{array}{c}\text { Strongly } \\
\text { agree }\end{array}$ & Agree & Neutral & Disagree & $\begin{array}{c}\text { Strongly } \\
\text { disagree }\end{array}$ \\
\hline 15 & 36 & 6 & 3 & \\
\hline \multicolumn{5}{r}{ Source: Client' Survey Data } \\
\hline
\end{tabular}

From the above table, it can tell that, most of the clients are strongly agreed \& agreed with existing policy.

Client's overall evaluation about foreign exchange department (Import, Export, Remittance related) service

\begin{tabular}{|c|c|c|c|c|}
\hline $\begin{array}{c}\text { Strongly } \\
\text { satisfied }\end{array}$ & Satisfied & Neutral & Dissatisfied & $\begin{array}{c}\text { Strongly } \\
\text { dissatisfied }\end{array}$ \\
\hline 45 & 12 & 3 & & \\
\hline \multicolumn{5}{c|}{ Source: Client' Survey Data } \\
\hline
\end{tabular}

From the above table, it can tell that, foreign exchange department of this bank provides very excellent service to the service taker.

Client's satisfaction with online banking service

\begin{tabular}{|c|c|c|c|c|}
\hline $\begin{array}{c}\text { Highly } \\
\text { satisfied }\end{array}$ & Satisfied & Neutral & Dissatisfied & $\begin{array}{c}\text { Highly } \\
\text { dissatisfied }\end{array}$ \\
\hline 48 & 9 & 3 & & \\
\hline \multicolumn{5}{|c}{ Source: Client' Survey Data } \\
\hline
\end{tabular}

From the above table it can tell that, this bank provides excellent online banking service to the people.

Client's problem using debit and credit card

\begin{tabular}{|l|l|}
\hline Yes & No \\
\hline 12 & 48 \\
\hline
\end{tabular}

Source: Client' Survey Data

The above table shows that, $80 \%$ clients do not feel problem use debit card \& rest of the $20 \%$ clients feel problem use debit card. 
Satisfied with no. of ATM booths

\begin{tabular}{|l|l|}
\hline Yes & No \\
\hline 18 & 42 \\
\hline
\end{tabular}

Source: Client' Survey Data

The table shows, 70\% clients told that, ATM booth is not available \& other $3 \%$ clients told that, ATM booth is available.

Safety and security in taking services

\begin{tabular}{|c|c|l|l|l|}
\hline $\begin{array}{c}\text { Strongly } \\
\text { agree }\end{array}$ & Agree & Neutral & Disagree & $\begin{array}{l}\text { Strongly } \\
\text { disagree }\end{array}$ \\
\hline 50 & 10 & & & \\
\hline \multicolumn{5}{|c|}{ Source: Client' Survey Data } \\
\hline
\end{tabular}

The table tells that, this bank is completely safe \& secure for providing services to the clients.

Get exact services what they need

\begin{tabular}{|c|c|l|l|l|}
\hline $\begin{array}{c}\text { Strongly } \\
\text { agree }\end{array}$ & Agree & Neutral & Disagree & $\begin{array}{c}\text { Strongly } \\
\text { disagree }\end{array}$ \\
\hline 40 & 20 & & & \\
\hline \multicolumn{5}{c}{ Source: Client' Survey Data } \\
\hline
\end{tabular}

From the above table it can tell that, this bank provides proper services to the parties when they come to the bank.

\section{Services comparing to time}

\begin{tabular}{|c|c|c|c|c|}
\hline $\begin{array}{c}\text { Strongly } \\
\text { agree }\end{array}$ & Agree & Neutral & Disagree & $\begin{array}{c}\text { Strongly } \\
\text { disagree }\end{array}$ \\
\hline 30 & 24 & 3 & 2 & 1 \\
\hline \multicolumn{4}{r}{ Source: Client' Survey Data } \\
\hline
\end{tabular}

From the above table it can tell that, 50\% clients strongly agreed, $40 \%$ clients agreed, $5 \%$ neutral, 3\% disagreed \& $2 \%$ strongly disagreed in terms of getting services in time.

Employee's co-operation in meeting queries and other needs

\begin{tabular}{|c|c|c|c|c|}
\hline $\begin{array}{c}\text { Strongly } \\
\text { agree }\end{array}$ & Agree & Neutral & Disagree & $\begin{array}{c}\text { Strongly } \\
\text { disagree }\end{array}$ \\
\hline 18 & 40 & 2 & & \\
\hline \multicolumn{4}{|c}{ Source: Client' Survey Data } \\
\hline
\end{tabular}

From the above table it can be told that, employees of this bank are co-operative in meeting queries and other needs.

\section{Efficiency in problem-solving}

\begin{tabular}{|c|c|c|c|c|}
\hline $\begin{array}{c}\text { Highly } \\
\text { satisfied }\end{array}$ & Satisfied & Neutral & Dissatisfied & $\begin{array}{c}\text { Highly } \\
\text { dissatisfied }\end{array}$ \\
\hline 6 & 48 & 3 & 3 & \\
\hline \multicolumn{5}{|c|}{ Source: Client' Survey Data } \\
\hline
\end{tabular}

From the above table, it can tell that, employees of this bank are efficient in problem-solving.

Client's loyalty rate to stay with this bank if any other bank/banks come up with the similar offers

\begin{tabular}{|l|l|}
\hline Yes & No \\
\hline 57 & 3 \\
\hline
\end{tabular}

Source: Client' Survey Data
The above table shows that, 95\% clients will be loyal to this bank if another bank come up with the similar offers but rest of the $5 \%$ clients will not be.

From the above survey result, it is clear that, people are satisfied as this bank is well enough in providing services. Findings clearly tell, in most of the dimensions or services criteria service takers are satisfied. In some minor areas they (the bank) are not reasonable as per the survey.

\section{Problems}

- Lack of clients' awareness about their policies.

- The branch consumes more time than expected.

- Inadequate exclusive promotional strategies.

- Very few number of ATM booths.

- Unavailability of schemes \& services such as Single Counter Service, Locker, etc.

- Unavailability of some loans and credits such as packing loan, Lease Finance, Project Finance, Doctors loan, Overseas Employment loan, etc.

- Inadequate employees to provide services to the clients.

\section{Recommendations}

- They would increase clients' awareness.

- They should increase load management capacity during peak hours to provide services quickly.

- They would try for some exceptional promotional strategies.

- They should make ATM booths available.

- They would try to introduce more schemes and services such as locker service.

- They need to observe services regularly.

- $\quad$ They would try to reduce tall formalities for sanctioning loans/making loan disbursement policy easy.

- $\quad$ They would provide more opportunity to the women entrepreneur.

\section{Conclusion}

Proper marketing of services is much needed for any organization, especially in the service organization all the time. Prime Bank Limited, Rangpur Branch is well enough for marketing its services \& attitude of the clients are positive towards their existing services. Finally, it can conclude that, the bank needs to think more about client services and the level of client satisfaction, the way to bring more speed for banking services, the way to achieve more efficiency and apply some strategies to boost up confidence to the clients.

\section{REFERENCES}

Abebe, E. (2014). The effect of service quality and core banking on customer satisfaction in commercial bank of Ethiopia. American Journal Of Trade And Policy, 1(2), Full Thesis. Retrieved from http://journals.abc.us.org/index.php/ajtp/article/view/Abebe 
Ahmed A, and Dey MM. 2009. Bank loan officers' perceptions of corporate financial disclosure in the banking sector of Bangladesh: An empirical analysis. Proceedings of the 2nd COMSATS International Business Research Conference, Lahore, Pakistan.

Ahmed AA and Ahmad M. 2009. An Empirical Analysis of Performance Measurement of the Disclosure in Financial Reporting: A Study of Banking Sector in Bangladesh COMSATS Institute if Information Technology 2nd COMSATS International Business Research Conference. Lahore, Pakistan: CIIT.

Ahmed AA and Dey MM. 2011. Accounting Disclosure Scenario: An Empirical Study of the Banking Sector of Bangladesh Accounting \& Management Information Systems, 9.

Ahmed AA and Siddique MN. 2013. Internet Banking Espousal in Bangladesh: A Probing Study Engineering International, 1, 40-47.

Ahmed AA, Dey MM, Akhter W and Raza A. 2011. Timeliness attributes and the extent of accounting disclosure: a study of banking companies in Bangladesh Interdisciplinary Journal of Contemporary Research in Business, 3, 915-925.

Ahmed AA. In:Business Management (https://www.lappublishing.com/), ed. 2012. Compliance of Financial Disclosure: Long Walk to Accounting Research 1 Germany: LAP LAMBERT Academic Publishing.

Airin Ara, U., \& Haque, E. (2015). Asset Liability Mismatch- An Empirical study on nationalized commercial banks in Bangladesh. Asian Business Review, 4(2), 11-19. Retrieved from http://journals.abc.us.org/index.php/abr/article/view/Ara

Akhter, M. (2014). Service Gap of Selected Public and Private Commercial Banks in Bangladesh.Global Disclosure Of Economics And Business, 1(2), 18-30. Retrieved from http://i-

scholar.in/index.php/GDEABC/article/view/54516

Awan, A. (2015). Brazil's Innovative Anti-Poverty \& Inequality Model. American Journal Of Trade And Policy, 1(3), 7-12. Retrieved http://journals.abc.us.org/index.php/ajtp/article/view/awan

Chowdhury, M., Halima Begum, M., Reza, R., \& Jannath, T. (2014). Micro Credit and Women Empowerment: A Study on Grameen Bank's Strategy of Poverty Alleviation. Global Disclosure Of Economics And Business, 2(2), 142-155. Retrieved from http://ischolar.in/index.php/GDEABC/article/view/54554

Fatema, M., Azad, M., \& Masum, A. (2015). Impact of Brand Image and Brand Loyalty in Measuring Brand Equity of Islami Bank Bangladesh Ltd.. Asian Business Review, 2(1), 42-46. Retrieved from http://journals.abc.us.org/index.php/abr/article/view/Fatema

Ferdous, M., \& Moniruzzaman, M. (2015). An Empirical Evidence of Corporate Social Responsibility by Banking Sector based on Bangladesh. Asian Business Review, 3(4), 82$87 . \quad$ Retrieved from http://journals.abc.us.org/index.php/abr/article/view/Ferdous

Hossain, M., Abdullah, A., \& Farhana, S. (2015). Performance Appraisal \& Promotion Practices on Private Commercial Bank in Bangladesh: A Case Study from Pubali Bank Ltd.. Asian Business Review, 1(1), 49-55. Retrieved from http://journals.abc.us.org/index.php/abr/article/vi ew $/ 1.8$ Hossain

Hossain, M., Irin, D., Islam, M., \& Saha, S. (2015). ElectronicBanking Services: A Study on Selected Commercial Banks in Bangladesh. Asian Business Review, 3(3), 53-61. Retrieved from http://journals.abc.us.org/index.php/abr/article/view/ HossainETEL

Lewis, R.C., \& Booms, B.H.(1980).The marketing aspects of service quality.

Masum, A. (2014). Dividend Policy and its Impact on Stock Price - A Study on Commercial Banks Listed in Dhaka Stock Exchange. Global Disclosure Of Economics And Business, 3(1), 09-17. Retrieved from http://ischolar.in/index.php/GDEABC/article/view/54523

Neogy, T. (2012). Evaluation of Financial Condition of Private Commercial Banks in Bangladesh: A Comparative Study. ABC Journal Of Advanced Research, 1(1), 16-27. doi: http://dx.doi.org/10.18034/abcjar.v1i1.10

Okpara, G., \& Onuoha, O. (2015). Bank Selection and Patronage By University Students: A Survey of Students in Umudike, Nigeria. Asian Business Review, 2(2), 12-18. Retrieved from http://journals.abc.us.org/index.php/abr/article/view/Okpara

Parasuraman, A., Zeithamal, V.A., \& Berry, L.L. (1986).SERVQUAL: A multiple-item scales for measuring customer perception of service quality. Marketing Service Institute, Cambridge, MA.

Rahman, M., Ahsan, M., Hossain, M., \& Hoq, M. (2015). Green Banking Prospects in Bangladesh. Asian Business Review, 2(2), 59-63. Retrieved from http://journals.abc.us.org/index.php/abr/article/vi ew/4.9Rahman

Redwanuzzaman, M., \& Islam, M. (2015). Problematic Issues of E-Banking Management in Bangladesh. Asian Business Review, 3(3), 26-30. Retrieved from http://journals.abc.us.org/index.php/abr/article/vi ew/Redwan

Saha, A., Hasan, K., \& Uddin, M. (2015). A Conceptual Framework for Understanding Customer Satisfaction in Banking Sector: The Mediating Influence of Service Quality and Organisational Oath. American Journal Of Trade And Policy, 1(3), 39-48. Retrieved from http://journals.abc.us.org/index.php/ajtp/article/view/Saha

Shahabuddin, A. (2014). Eservice Quality for Customer Satisfaction Measurement: A Case Study on Islami Bank Bangladesh Ltd. Global Disclosure Of Economics And Business, 3(1), 32-39. Retrieved from http://ischolar.in/index.php/GDEABC/article/view/54527

Siddique, M. (2015). Bank Selection Influencing Factors: A Study on Customer Preferences with Reference to Rajshahi City. Asian Business Review, 1(1), 80-87. Retrieved from http://journals.abc.us.org/index.php/abr/article/view/1 .12Siddique

Tuli, F. (2015). Corporate Social Activities of Private Commercial Banks in Bangladesh: An Evaluation. Asian Business Review, 4(2), 38-40. Retrieved from http://journals.abc.us.org/index.php/abr/article/vi ew/Tuli

Zeithaml, A., Berry, L., Parasuraman, V. A. (April 1996).The Behavioral Consequences of Service Quality. Journal of Marketing, pp. 31-46.

Zhang, X., \& Feng, Y.(2009). The Impact of Customer Relationship Marketing Tactics on Customer Loyaltywithin Swedish Mobile Telecommunication Industry. School of Business and Engineering. Halmstad University.

$$
\text { -- } 0 \text {-- }
$$

